\title{
Saúde Mental e Apoio Psicossocial em Emergências Humanitárias: uma análise crítica entre políticas e práticas atuais de assistência
}

\begin{abstract}
Resumo
Gagliato, Marcio F. Saúde Mental e Apoio Psicossocial em Emergências Humanitárias: uma análise crítica entre políticas e práticas atuais de assistência [tese]. São Paulo: Faculdade de Saúde Pública
\end{abstract} da USP; 2018. $163 f$

Existe uma tensão extraordinária no sistema humanitário: crises e emergências atingem cada vez mais povos, duram mais e são gradativamente mais complexas. As consequências dos conflitos armados e desastres socioambientais para a saúde mental e bem-estar psicossocial de indivíduos e povos, bem como para a ecologia social e os recursos comunitários significativos, já são reconhecidas e continuamente pesquisadas. Esta tese, a seu turno, explora as práticas e políticas do setor de Saúde Mental em emergências humanitárias e toma como ponto de partida analítico o desenvolvimento das Diretrizes do Comitê Permanente Interagências (IASC) em Saúde Mental e Apoio Psicossocial (SMAPS) em emergências humanitárias, lançadas no ano de 2007, assim como sua subsequente disseminação e configuração de governança, além de sua influência sobre projetos e instituições. As diretrizes IASC representam um marco lógico de importante contribuição para o setor de ajuda humanitária, no entanto, ainda constituem um campo de várias disputas e paradoxos, não só na área das referências teóricas e práticas em SMAPS em emergências humanitárias, como também relativamente à sua inserção em uma economia-política do setor de ajuda humanitária paradoxal nos princípios humanitários e éticos. Essa inserção molda as características particulares do funcionamento das Diretrizes e influencia a maneira como se produzem práticas e políticas. Fundamentando-se na pesquisa-ação, nas experiências do autor, o qual atuou como psicólogo na linha de frente em crises humanitárias na Líbia, Gaza, Síria, Timor-Leste e outros contextos, e em entrevistas com atores internacionalmente renomados e responsáveis pela elaboração e gestão de políticas internacionais do setor global de SMAPS, esta tese examina esse processo em detalhe, considerando o desenvolvimento e evolução das Diretrizes IASC de SMAPS e como, atualmente, a área de SMAPS se configura no interior da economia-política do setor humanitário. Mais explicitamente, analisam-se as maneiras como o discurso e a prática do setor de SMAPS são transformados pela estrutura humanitária que ele engendra. Desse modo, e por meio da discussão de todos esses elementos, este trabalho objetiva realizar uma revisão de elementos que influenciam e permitem o desenvolvimento de assistência humanitária seja cooptada em formas particulares que se articulam a interesses não humanitários, moldando substancial e prejudicialmente os projetos de SMAPS em emergências humanitárias ao redor do mundo.

Palavras-chave: Saúde Mental; Apoio Psicossocial; Emergências Humanitárias; Psicologia em Emergências; Economia Política da Ajuda Humanitária 


\begin{abstract}
Gagliato, Marcio F. The Political Economy of Mental Health and Psychosocial Support in Humanitarian Emergencies: a critical analysis of current practices [thesis]. São Paulo: USP Faculty of Public Health; 2018. 163p

There is extraordinary strain placed on the humanitarian system. Crises and emergencies are occurring more often, affecting more people, and in contexts of increasingly complexity. The impacts of conflict and disaster on mental health as well as on the social ecology and community resources needed for coping and recovery are very well documented. This research explores the politics of mental health and psychosocial programmes in humanitarian settings, and its analytical starting point is the development of the Interagency Standing Committee (IASC) Guidelines on Mental Health and Psychosocial Support (MHPSS) in Emergencies settings launched in the year of 2007. The research explores how the field was developed, its structural governance, trying to explore the political economy configuration of humanitarian organizations providing MHPSS in its discourses, practices and impact. It is demonstrated the MHPSS IASC guidelines unprecedent contribution to the field, however it shows how it is affected by the political economy of aid that it is fundamentally part of. This structural political economy shapes the field and influences the way SMAPS is provided. Using action research, the author's own experiences responding to several humanitarian crises for more than 14 years, and interviews with well-known global MHPSS policy makers, this thesis examines this process in detail, considering how the development of the guidelines has developed and evolved, and how the area currently shapes in the political economy of aid. More explicitly, it analyzes the ways in which the discourse and practice of the MHPSS field are transformed by the humanitarian structure it engenders. Despite the field achievements, action research illustrates that this process allows the development of MHPSS response to be co-opted in particular ways that articulate non-humanitarian interests, substantially and harmfully influencing the MHPSS responses.
\end{abstract}

Key words: Mental Health; Psychosocial Support; Humanitarian Emergencies; Psychology in emergencies; Political Economy of Aid 